\title{
Comparative Study of Antioxidant Potentials of Methanol Fruit Extracts of Morinda citrifolia and Morinda lucida
}

\author{
C. J. Ezenwaka ${ }^{1}$, P. N. Uzoegwu ${ }^{1,2}$, A. C. Nwaka ${ }^{1}$, and P. O. Alaebo ${ }^{1}$ \\ ${ }^{1}$ Department of Biochemistry, Faculty of Natural Sciences, Chukwuemeka Odumegwu Ojukwu University, Anambra State, Nigeria. \\ ${ }^{2}$ Department of Biochemistry, Biological Sciences, University of Nigeria Nsukka, Enugu, Nigeria \\ *Corresponding author's e-mail: chommyokoye@yahoo.com
}

\begin{abstract}
Herbal preparations of different Morinda plant species had been used as supplements and for therapeutic purposes with less emphasis on the bioactive components. This study is aimed at investigating the in vitro antioxidant potentials of methanol fruit extracts of Morinda citrifolia (MCE) and Morinda lucida. The potent bioactive agents in MCE and MLE were extracted with $90 \%$ methanol. Both plants species did not have catalase activity but scavenged 1, 1-diphenl-2picrylhydrazyl radical (DPPH) in concentration dependent manner against percentage inhibition showing effective concentration at 50\% inhibition $\left(\mathrm{EC}_{50}\right)$ of $716.09 \mu \mathrm{g} / \mathrm{ml}$ and $910.24 \mu \mathrm{g} / \mathrm{ml}$ for MCE and MLE compared to that of vitamin C standard with the $\mathrm{EC}_{50}$ of $54.61 \mu \mathrm{g} / \mathrm{ml}$. The MCE and MLE scavenged superoxide (SO) radical in concentration dependent manner with the $\mathrm{EC}_{50}$ of $72.77 \mu \mathrm{g} / \mathrm{ml}$ and $82.43 \mu \mathrm{g} / \mathrm{ml}$ respectively compared to that of vitamin C standard with $\mathrm{EC}_{50}$ of $176.08 \mu \mathrm{g} / \mathrm{ml}$. Also, MCE and MLE scavenged nitric oxide (NO) radical in concentration dependent manner with the $\mathrm{EC}_{50}$ of $2198.32 \mu \mathrm{g} / \mathrm{ml}$ and $3734.26 \mu \mathrm{g} / \mathrm{ml}$ compared to that of vitamin $\mathrm{E}$ standard with $\mathrm{EC}_{50}$ of $1700.73 \mu \mathrm{g} / \mathrm{ml}$. Both MCE and MLE scavenged hydroxyl $(\mathrm{OH})$ radical in concentration dependent manner with the $\mathrm{EC}_{50}$ of $134.32 \mu \mathrm{g} / \mathrm{ml}$ and $155.07 \mu \mathrm{g} / \mathrm{ml}$ respectively compared to that of vitamin $\mathrm{E}$ standard with $\mathrm{EC}_{50}$ of $54.33 \mu \mathrm{g} / \mathrm{ml}$. These might imply that MCE is a better antioxidant than MLE. The MLE contained more vitamin A $(2,438 \pm$ 0.1 i.u) than MCE $(1,323 \pm 0.3$ i.u $)$ while MCE vitamin C $(10.80 \pm 0.05 i . u)$ and vitamin E ( $0.15 \pm 0.2$ i.u) contents was higher than that of MLE (vitamin C (7.40 0.02 i.u and vitamin E (0.14 \pm 0.01 i.u). These could also imply that MCE had more antioxidant activity and could be preferred in Nigeria folk medicine.
\end{abstract}

Original Research Article

Received: $22^{\text {nd }}$ Feb., 2018 Accepted: $10^{\text {th }}$ Mar., 2018 Published: $14^{\text {th }}$ Mar., 2018

Keywords:

Phytochemicals Antioxidant Effective concentration Scavenged

\section{INTRODUCTION}

$\mathrm{P}$ lants contain biochemical components that can be extracted and used in the preparation of drug, or used directly as medication. These medicinal plant preparations are administered to man with the hope of promoting health and treating various diseases. Immense benefits have been derived by man from using medicinal herbs in disease management because they are relatively safer, more affordable and sometime offer better therapeutic values than synthetic drugs (Oyewole and Akigbala, 2011). One of these medicinal plants is Morinda. It is in a genus of flowering plants in the madder family, Rubiaceae. Its generic name is derived from the Latin words morus "mulberry", from the appearance of the fruits, and indica, meaning "of India". There are about 80 species of Morinda trees although the species of interest in this work are Morinda citrifolia and Morinda lucida. Morinda citrifolia Linn Rubiaceae is one of the most important traditional Polynesian medicinal plant commercially known as Noni, Indian mulberry, Cheese fruit and indigenously found in open coast region at sea level and in forest areas about 1,300 feet above sea level. It is a small tropical evergreen shrub or tree, three to twelve meters high. It has straight trunk, large green leaves and distinctive grenade like yellow fruit. The size of the fruit is about $12 \mathrm{~cm}$ due to coalescence of the interior ovaries of many closely packed flowers and it has a foul taste and a soapy smell when ripe. The fruit of this plant has been used as food, drink, 
medicine, colourful dye, cosmetics purpose and has a high demand in medicines for different kinds of illnesses like diabetes, high blood pressure, AIDS, arthritis, cancer, gastric ulcer, sprains, mental depression, senility, poor digestion, atherosclerosis, blood vessel problem etc., (Kochuthressia and Jaseentha, 2015). On the other hand, M. lucida is an evergreen shrub or small to medium-sized tree bearing a dense crown of slender, crooked branches. It can grow from 2.4 - 18 metres tall, although plants of 25 metres are recorded in coastal Cote D'Ivoire. The branches are often crooked or gnarled and it is a multipurpose species yield dyes, timber, fuel and traditional medicines. The roots are sold in local shops and markets, both as dyestuff and medicine, whilst the leaves and twigs are sold as a medicinal tonic for young children.

The ability of Morinda to perform these curative actions is because of the presence of phytochemicals and antioxidants (Webbi, 2013). Antioxidants are a class of molecules that are capable of inhibiting the oxidation of another molecule (Becker et al., 2004). The body naturally circulates various nutrients due to their antioxidant properties. It also manufactures antioxidant enzymes in order to control free radical chain reactions. Some antioxidants are produced by the body, but some are not. The body's natural antioxidant production can decline with age. Antioxidants play a significant role in one's health, as they can control how fast a man age by fighting free radicals.

Free radicals are atoms or groups of atoms with an odd (unpaired) number of electrons and can be formed when oxygen interacts with certain molecules (Ananya, 2016). Once formed these highly reactive radicals can start a chain reaction, like dominoes. Their chief danger comes from the damage they can do when they react with important cellular components such as DNA, or the cell membrane. Cell damage caused by free radicals appears to be a major contributor to aging and diseases like cancer, heart disease, decline in brain function, decline in immune system etc.

The $M$. citrifolia and $M$. lucida contain antioxidants like vitamin C, vitamin E, and A (Adejo et al., 2015). Vitamin C is the most important water-soluble antioxidant in the extracellular fluids. Vitamin $\mathrm{C}$ helps to neutralize reactive oxygen species (ROS) in the water or aqueous phase before it can attack the lipids. Vitamin $\mathrm{E}$ is the most important lipid soluble antioxidant. It is important as the chain-breaking antioxidant within the cell membrane. It can protect the membrane fatty acids from lipid peroxidation. Vitamin $\mathrm{C}$ in addition is capable of regenerating vitamin $\mathrm{E}$. Beta carotene and other carotenoids also have antioxidant properties. Carotenoids work in synergy with vitamin E. Both Morinda species also scavenged superoxide, nitric oxide, hydroxyl and 1, 1-diphenl-2-picrylhydrazyl radical.

Most plants with high antioxidant potentials are believed to be medicinal plants. Thus, this work will compare the antioxidant potentials of methanol fruit extracts of Morinda citrifolia and Morinda lucida to determine the specie that will be preferred in traditional medicine.

\section{Plant Materials Sample (Morinda citrifolia)}

The $M$. citrifolia and M. lucida fruits were obtained from Hezekiah Dike Street, Obinagu, Awka and Nnamdi Azikiwe University Awka plantation. These plants were identified in the Botany laboratory of Nnamdi Azikiwe University. A voucher specimen was deposited in the herbarium of the University and was authenticate by Dr. B. O. Aziagba with the herbarium numbers, page 14, cabinet 2 and shelf 35 . The fruits were dried in an oven at $50^{\circ} \mathrm{C}$, soaked for 48 hours and extracted with $90 \%$ Lobachem methanol.

\section{Preparation of fruit Extract}

Morinda fruits were rinsed with distilled water and dried in an oven at $50^{\circ} \mathrm{C}$ for twelve (12) hours. The dried fruits were grinded into powder with a manual blender. Four hundred and fifty grams (450 gms) of the dried fruit powder was macerated in seven hundred millilitres $(700 \mathrm{ml})$ of $99 \%$ Lobachem methanol, agitated for 5 minutes with an electric blender and left for 48 hours at room temperature. The mixture was pressed with a muslin cloth and then filtered with Whatmann No.1 filter paper. Then, different quantities of the methanolic extract of Morinda were used for the vitamins and antioxidant analysis.

Chemicals: All chemicals used were of analytical grade.

\section{METHODS}

The catalase activity was assayed using colorimeter as described by Beers and Sizer, 1952.

DPPH radical scavenging activity was measured using spectrophotometric method as described by Ahmed et al., (2015).

Hydroxyl radical scavenging activity was measured according to method described by Halliwell et al., (1987).

Nitric oxide scavenging activity was determined according to Rozina et al., 2012.

Superoxide (SO) radical scavenging assay determined by $\mathrm{Yu}$ et al., 2003.

Determinations of antioxidant vitamins (A, C and E) in the extract were done using the following methods;

Vitamin A; Spectrophotometry method as described by Plummer, (1978).

Vitamin C; Titration method as described by John and Bernard, 1990.

Vitamin E; Titration method as described by Kayden et al., (1973).

\section{Statistical Analysis}

Data were reported as means \pm S.D, where appropriate. Student T-test and correlation analysis were used to analyse 
the research data using Statistical Packages for Social Sciences (SPSS) version 16. Differences were considered significant when $\mathrm{p}<0.05$ and $\mathrm{p}<0.01$.

\section{RESULTS}

Percentage yield (M. citrifolia)

$$
\begin{aligned}
& =\frac{\text { Extract weight }}{\text { Crude weight }} \times 100 \\
& \qquad=\frac{23.08}{452.32} \times 100=5.10 \%
\end{aligned}
$$

Percentage yield $(M$. lucida $)=\frac{\text { Extract weight }}{\text { Crude weight }} \times 100$

$$
=\frac{27.54}{468.57} \times 100=5.88 \%
$$

Table 1: Scavenging effect of extracts on DPPH radical

\begin{tabular}{llll}
\hline $\begin{array}{l}\text { Concentration } \\
(\boldsymbol{\mu g} / \mathbf{m l})\end{array}$ & \multicolumn{3}{l}{ Percentage Inhibition (\%) } \\
\hline & MCE & MLE & $\begin{array}{l}\text { Vitamin C } \\
\text { (Standard) }\end{array}$ \\
1000 & 64.51 & 54.48 & 96.01 \\
500 & 44.33 & 28.51 & 95.04 \\
250 & 23.69 & 14.25 & 92.32 \\
200 & 11.40 & 11.40 & 92.14 \\
100 & 9.47 & 5.70 & 91.56 \\
\hline
\end{tabular}

$\mathrm{EC}_{50}$ for $\mathrm{MCE}=716.09 \mu \mathrm{g} / \mathrm{ml}, \mathrm{EC}_{50}$ for $\mathrm{MLE}=910.24 \mu \mathrm{g} / \mathrm{ml}$

$\mathrm{EC}_{50}$ for vitamin $\mathrm{C}($ Ascorbic acid $)=\quad 54.61 \mu \mathrm{g} / \mathrm{ml}$

Table 1 shows the scavenging effect of MCE and MLE on DPPH radical. The quantitative DPPH assay showed a decolouring effect of the purple colour of the DPPH radical to yellow after both extracts were incubated with it for 30 minutes. From this table, it was deduced that the two extracts scavenged DPPH radical in concentration dependent manner with the highest percentage inhibition of 64.51 and 54.48 for MCE and MLE respectively. The effective concentration at which the extract can scavenge $50 \%$ of the free radical present $\left(\mathrm{EC}_{50}\right)$ are $716.09 \mu \mathrm{g} / \mathrm{ml}$ and $910.24 \mu \mathrm{g} / \mathrm{ml}$ for MCE and MLE respectively compared with that of vitamin $C$ (Ascorbic acid) of $54.61 \mu \mathrm{g} / \mathrm{ml}$ ). Both MLE and MCE concentration against percentage inhibition showed a statistically positive significant correlation $(\mathrm{p}<0.01)$ with correlation coefficient $\left(\mathrm{R}^{2}\right)$ of 0.986 and 0.971 indicating that MCE could be a better antioxidant than MLE.

Table 2: Scavenging effect of extracts of MCE and MLE on Superoxide radical.

\begin{tabular}{llll}
\hline $\begin{array}{l}\text { Concentration } \\
(\boldsymbol{\mu g} / \mathbf{m l})\end{array}$ & \multicolumn{3}{l}{ Percentage Inhibition (\%) } \\
\hline & MCE & MLE & $\begin{array}{l}\text { Vitamin C } \\
\text { (Standard) }\end{array}$ \\
1000 & 92.85 & 88.23 & 70.35 \\
500 & 88.56 & 76.37 & 65.80 \\
250 & 85.56 & 68.57 & 52.40 \\
200 & 84.56 & 65.01 & 50.74 \\
100 & 68.75 & 60.66 & 43.80 \\
\hline
\end{tabular}

$\mathrm{EC}_{50}$ for $\mathrm{MCE}=72.77 \mu \mathrm{g} / \mathrm{ml}, \mathrm{EC}_{50}$ for $\mathrm{MLE}=82.43 \mu \mathrm{g} / \mathrm{ml}$
$\mathrm{EC}_{50}$ for vitamin $\mathrm{C}($ Ascorbic acid $)=176.08 \mu \mathrm{g} / \mathrm{ml}$

Table 2 shows the results of the scavenging effect of MCE and MLE on superoxide radical. From this table, it was deduced that the two extracts scavenged superoxide radical in concentration dependent manner with the highest percentage inhibition of $92.85 \%$ and $88.23 \%$ for MCE and MLE respectively. The effective concentration at which the extract scavenged $50 \%$ of the free radical present $\left(\mathrm{EC}_{50}\right)$ for $\mathrm{MCE}$ and MLE were $72.77 \mu \mathrm{g} / \mathrm{ml}$ and $82.43 \mu \mathrm{g} / \mathrm{ml}$ respectively compared with that of vitamin $\mathrm{C}$ (Ascorbic acid) of $197.08 \mu \mathrm{g} / \mathrm{ml}$ ). The MLE extracts concentration against percentage inhibition showed a statistically positive significant correlation $(\mathrm{p}<0.01)$ with correlation coefficient $\left(\mathrm{R}^{2}\right)$ of 0.988 while that of MCE showed non positive statistically correlation $(p>0.01)$ with correlation coefficient $\left(\mathrm{R}^{2}\right)$ of 0.756 indicating that $\mathrm{MCE}$ has more antioxidant potential.

Table 3: Scavenging effect of MCE and MLE on Hydroxyl radical.

\begin{tabular}{llll}
\hline $\begin{array}{l}\text { Concentration } \\
(\boldsymbol{\mu g} / \mathbf{m l})\end{array}$ & \multicolumn{3}{l}{ Percentage Inhibition (\%) } \\
\hline & MCE & MLE & $\begin{array}{l}\text { Vitamin E } \\
\text { (Standard) }\end{array}$ \\
100 & 49.45 & 48.84 & 85.98 \\
64 & 47.94 & 46.88 & 79.67 \\
32 & 47.49 & 46.27 & 69.10 \\
12.8 & 47.22 & 46.21 & 41.80 \\
6.4 & 47.12 & 46.00 & 15.74 \\
\hline
\end{tabular}

$\mathrm{EC}_{50}$ for $\mathrm{MCE}=134.32 \mu \mathrm{g} / \mathrm{ml}, \mathrm{EC}_{50}$ for $\mathrm{MLE}=155.07 \mu \mathrm{g} / \mathrm{ml}$

$\mathrm{EC}_{50}$ for vitamin $\mathrm{E}($ Alpha-tocopherol $)=54.33 \mu \mathrm{g} / \mathrm{ml}$.

Table 3 represents the scavenging effect of MCE and MLE on hydroxyl radical. The analysis showed that the MCE and MLE scavenged hydroxyl radical in concentration dependent manner with the highest percentage inhibition of 49.45 and 48.84 respectively. The effective concentration at which the extracts can scavenge $50 \%$ of the free radical present $\left(\mathrm{EC}_{50}\right)$ for MCE and MLE were $134.32 \mu \mathrm{g} / \mathrm{ml}$ and $155.07 \mu \mathrm{g} / \mathrm{ml}$ respectively compared with that of vitamin $\mathrm{C}$ (Ascorbic acid) of $197.08 \mu \mathrm{g} / \mathrm{ml}$ ). The MCE extracts concentration against percentage inhibition showed a statistically positive significant correlation $(\mathrm{p}<0.01)$ with correlation coefficient $\left(\mathrm{R}^{2}\right)$ of 0.963 while that of MLE showed significant statistically positive correlation $(\mathrm{p}<0.05)$ with correlation coefficient $\left(\mathrm{R}^{2}\right)$ of 0.946 . Here, vitamin $\mathrm{E}$ was more effective scavenger than the extracts but MCE has more antioxidant power than MLE.

Table 4: Scavenging effect of MCE and MLE on Nitric oxide radical.

\begin{tabular}{llll}
\hline $\begin{array}{l}\text { Concentration } \\
(\boldsymbol{\mu g} / \mathbf{m l})\end{array}$ & \multicolumn{3}{l}{ Percentage Inhibition (\%) } \\
& MCE & MLE & $\begin{array}{l}\text { Vitamin E } \\
\text { (Standard) }\end{array}$ \\
1000 & 26.50 & 18.50 & 31.70 \\
500 & 26.14 & 14.16 & 4.12 \\
250 & 17.10 & 11.92 & 13.00 \\
200 & 16.95 & 11.29 & 0.00 \\
100 & 8.60 & 6.41 & 3.61 \\
\hline
\end{tabular}


$\mathrm{EC}_{50}$ for $\mathrm{MCE}=2198.32 \mu \mathrm{g} / \mathrm{ml}, \quad \mathrm{EC}_{50}$ for $\mathrm{MLE}=$ $3734.26 \mu \mathrm{g} / \mathrm{ml}$,

\section{$\mathrm{EC}_{50}$ for vitamin $\mathrm{E}=1700.73 \mu \mathrm{g} / \mathrm{ml}$}

Table 4 represents the scavenging effect of MCE and MLE on nitric oxide radical. The analysis showed that the MCE and MLE weakly scavenged nitric oxide radical in concentration dependent manner with the highest percentage inhibition of $18.50 \mu \mathrm{g} / \mathrm{ml}$ and $26.50 \mu \mathrm{g} / \mathrm{ml}$ respectively. The effective concentration at which the extracts can scavenge $50 \%$ of the free radical present $\left(\mathrm{EC}_{50}\right)$ for MCE and MLE were of $2198.3 \mu \mathrm{g} / \mathrm{ml}$ and $23734.26 \mu \mathrm{g} / \mathrm{ml}$ respectively compared with that of vitamin $\mathrm{E}$ of $157.73 / \mathrm{ml}$ ). The MLE extracts concentration against percentage inhibition showed a statistically positive significant correlation $(\mathrm{p}<0.05)$ with correlation coefficient $\left(\mathrm{R}^{2}\right)$ of 0.931 while that of $\mathrm{MCE}$ showed non-significant statistically positive correlation $(\mathrm{p}>0.05)$ with correlation coefficient $\left(\mathrm{R}^{2}\right)$ of 0.836 indicating that $\mathrm{MCE}$ has more antioxidant power.

Comparison of the Anti-Radical Power (ARP) of the extracts Against 1, 1-Diphenyl-2-picrylhydrazyl (DPPH) Radical, Nitric oxide Radical, Superoxide Radical and Hydroxyl Radical Scavenging Activity

Fig. 1 represents the anti-radical power of MCE and MLE fruit against different free radicals. ARP were calculated as the inverse of $\mathrm{EC}_{50}$ of those radicals. The ARP of MCE against superoxide radical was the highest, showing that MCE extract had the ability to quench superoxide radical more than the DPPH, nitric and hydroxyl radicals when compared to that of MLE extract while MLE had the least ability to scavenge nitric oxide radical more than DPPH, superoide and hydroxyl radicals when compared to that of MCE.

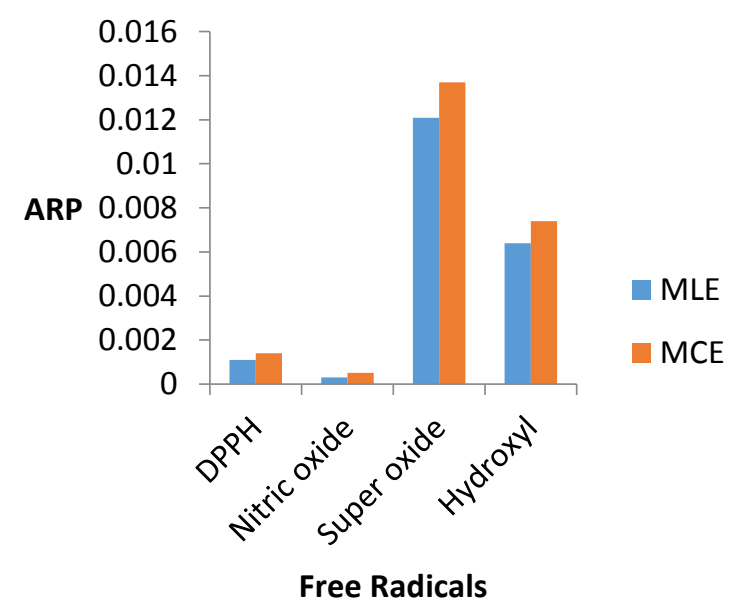

Fig. 1: Anti Radical Power of MCE and MLE against different free radical.

Table 5: Vitamin content of MCE and MLE.

\begin{tabular}{lll}
\hline Vitamins & Values (I.U) & \\
\hline Vitamin A & $1,323 \pm 0.3$ & $2,438 \pm 0.1$ \\
Vitamin C & $10.80 \pm 0.051$ & $7.40 \pm 0.02$ \\
Vitamin E & $0.15 \pm 0.21$ & $0.14 \pm 0.01$ \\
\hline
\end{tabular}

Table 4 displays the vitamin concentrations of MCE and MLE fruits. The MLE had higher vitamin A concentration $(2,438 \pm 0.1$ I. U) than MCE $(1,323 \pm 0.3$ I. U) while MCE had higher vitamin $E$ concentration $(0.15 \pm 0.2 \mathrm{I}$. U) than MLE $(0.14 \pm 0.01$ I. U). Also, MCE had higher water soluble vitamin C concentration $(10.80 \pm 0.05$ I. U) than MLE

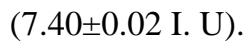

\section{DISCUSSION}

Different plant parts are made up of bioactive compound which avail them the ability to mop-up free radicals. Antioxidants are mainly responsible for this effect. This work compares the in vitro antioxidant potentials of methanol fruit extract of Morinda citrifolia (MCE) and Morinda lucida (MLE).

The results of the in vitro antioxidant potentials showed that MCE and MLE had free radical scavenging activities for 1 , 1-diphenyl-2-picryl-hydrazyl (DPPH), nitric oxide, hydroxyl and superoxide radicals. There was no catalase activity in MCE and MLE. This was not in line with Srinivasanan and Durairaj, (2014) that detected catalase activity in $M$. citrifolia. The absence of catalase is because methanol provokes a decrease in the activity and concentration of antioxidant enzymatic as well as non-enzymatic parameters thereby causing enhanced membrane peroxidation of phospholipids (Skrzydlewska, 2003). Catalase converts hydrogen peroxide into water and oxygen, using iron and manganese as cofactors (Chelikani et al., 2004) thereby, finished up the detoxification process started by superoxide dismutase (SOD).

The result showed that the effective concentration of extract that caused $50 \%$ inhibition of free radicals $\left(\mathrm{EC}_{50}\right)$ of $1,1-$ diphenyl-2-picrylhydrazyl (DPPH) radical for MLE $(910.24 \mu \mathrm{g} / \mathrm{ml})$ was significantly higher $(\mathrm{p}<0.05)$ than that of MCE $(716.09 \mu \mathrm{g} / \mathrm{ml})$. This could imply that MCE had more scavenging activity or antioxidant activity than MLE although their scavenging activity was lower when compared with the standard vitamin $\mathrm{C}$ of $\mathrm{EC}_{50}(54.61 \mu \mathrm{g} / \mathrm{ml})$. The $\mathrm{EC}_{50}$ of superoxide (SO) radical for $\operatorname{MLE}(82.43 \mu \mathrm{g} / \mathrm{ml})$ was significantly higher $(\mathrm{p}<0.05)$ than that of $\mathrm{MCE}(72.77 \mu \mathrm{g} / \mathrm{ml})$. This could suggest that MCE had higher superoxide radical scavenging activity than MLE. But both extracts were better superoxide radical scavengers when compared with the standard vitamin $\mathrm{C}$ of $\mathrm{EC}_{50}(197.08 \mu \mathrm{g} / \mathrm{ml})$. The $\mathrm{EC}_{50}$ of hydroxyl $(\mathrm{OH})$ radical for MCE $(141.45 \mu \mathrm{g} / \mathrm{ml})$ was nonsignificantly lower $(\mathrm{p}>0.05)$ than that of MLE ( $\mathrm{EC}_{50} 172.98$ $\mu \mathrm{g} / \mathrm{ml})$. This could indicate that the antioxidant activity of MCE was slightly higher than that of MLE. The $\mathrm{EC}_{50}$ of nitric oxide (NO) radical for MLE $(3676.60 \mu \mathrm{g} / \mathrm{ml})$ was significantly higher $(\mathrm{p}<0.05)$ than that of MCE of $\mathrm{EC}_{50}$ $(2198.32 \mu \mathrm{g} / \mathrm{ml})$. This could mean that the antioxidant activity of MCE was higher than that of MLE. Meanwhile, both extracts were weak antioxidants when compared with the standard vitamin $\mathrm{E}$ of $\mathrm{EC}_{50}(157.61 \mu \mathrm{g} / \mathrm{ml})$.

From the above results both extracts scavenged DPPH, SOD, $\mathrm{OH}$ and NO radicals so, it could be suggested that they had antioxidant activity (Rahman and Moon, 2007; (Hasan et al., 2008). When there is an imbalance between the free radicals and the antioxidant, it results to oxidative injury which is the 
fundamental mechanism underlying a number of human neurologic and other disorders such as inflammation, viral infections, autoimmune pathologies, and digestive system disorders including gastrointestinal inflammation and ulcer (Aruoma, 2003).

Vitamin A, C and E are non-enzymatic antioxidants (Shahidi and Zhong, 2010). They play crucial roles in preventing peroxidation damage in the biological system (Fogliano et al., 1999; Mantena et al., 2003). The result of vitamin concentrations of the extracts supported Dixon et al. (1999) report which stated that the vitamins in the MCE are mainly ascorbic acid and provitamin A. Extracts from both plant species had very high vitamin A concentrations of 1,323 \pm 0.3 I.U and 2,438.48 \pm 0.1 I.U for MCE and MLE respectively with vitamin A content of MLE being significantly higher $(p<0.05)$ than that of MCE indicating that MLE could be a better antioxidant than MCE. The vitamin $\mathrm{C}$ concentration of MCE $(10.80 \pm 0.05$ I.U) was significantly higher $(p<0.05)$ than that of MLE (7.4 \pm 0.02 I.U). This result supported the claims of anticancer effect of both extracts since vitamin $\mathrm{C}$ plays a laudable role in the prevention and treatment of cancer (Carr and Frei, 1999; Li and Schellhorn, 2007). The vitamin $\mathrm{E}$ concentrations of $0.15 \pm 0.2 \mathrm{I}$. $\mathrm{U}$ for $\mathrm{MCE}$ was not significantly higher $(p>0.05)$ than that of MLE with $0.14 \pm 0.01 \mathrm{I}$. U. Both extracts had low vitamin E content when compared with the recommended daily allowance (RDA) of 28 I.U (National Academy Press, 2000). This result also is suggestive of the fact that both extracts should possibly have low effect in preventing the formation of blood clots that could lead to heart attack or venous thromboembolism (Glynn et al., 2007).

\section{CONCLUSION}

Morinda citrifolia and Morinda lucida plants are used in folk medicine because of their high antioxidant activity. These plants contained the fat soluble vitamin A (a good source of vitamin $\mathrm{A}$ ) and the water soluble vitamins $\mathrm{B}$ and $\mathrm{C}$. They have moderate to strong scavenging activity for DPPH, SO, $\mathrm{OH}$ and NO radicals with no catalase activity. These antioxidants might have contributed to the use of these plants both as supplement and for therapeutic purposes. Nevertheless, MCE might be a better antioxidant than MLE and could be preferred in folk medicine.

\section{Contribution to knowledge}

Morinda citrifolia is more potent than Morind lucida.

\section{ACKNOWLEDGEMENT}

We thank all authors whose works were used for this review. Ezenwaka, C. J. specially thank all the lecturers of the Department of Biochemistry, Chukwuemekaodumegwu Ojukwu University, Uli Campus Nigeria, for their expatriate contribution during the course of the write up.

\section{REFERENCES}

Adejo, G. O., Akintayo, C. O. and Obinna, M. (2015). Morinda lucida leaf and fruit extracts may attenuate diarrhea arising from ebola. Basic Research of Medicine and Clinical Journal. 3(4):95-100.

Ahmed, D., Khan, M. M. and Saeed, R. (2015). Comparative Analysis of Phenolics, Flavonoids and Antioxidant and Antibacterial Potential of Methanolic, hexanic and aqueous extract from Adiantum Caudatum leaves. Antioxidants. 4: 394409.

Ananya, M. D. (2016). What is Oxidative Stress? https://www.news-medical.net /health / What-isOxidative-Stress.aspx. Retrieved on $25^{\text {th }}$ June, 2017.

Aruoma, O. I (2003). Methodological considerations for characterizing potential antioxidant actions of bioactive components in food plants. Mutat. Res. Journal. 523 -524:920

Becker, E. M., Nissen, L. R. and Skibsted, L. H. (2004). Antioxidant evaluation protocols: Food quality or health effects. Eur. Food Res. Technol. Journal. 219: 561-571.

Beers, R. F. and Sizer, I. W (1952). A spectrophotometric method for measuring the breakdown of $\mathrm{H}_{2} \mathrm{O}_{2}$ by catalase. Journal of Biological Chemistry. 195: 134-140.

Carr, A. and Frei, B. (1999). Does vitamin C act as a pro-oxidant under physiological conditions? FASEB, Journal. 13:1007-24.

Chelikani, P., Fita I, Loewen, P. C. (2004). "Diversity of structures and properties among catalases". Cellular and Molecular Life Sciences, Journal. 61 (2): 192-208.

Dietary Reference Intakes for Vitamin A, Vitamin K and Zinc (2001).

Dietary Reference Intakes for Vitamin C, Vitamin E, Selenium, and Carotenoids (2000)

Dixon, A. R., McMillan, H. and Etkin, N. L. (1999). The transformation of Noni traditional Polynesian medicine (Morinda citrifolia, Rubiaceae). Econ. Bot. Journal.53:51-68.

Fogliano, V., Verde, V., Randazzo, G. and Ritieni, A. (1999). Method for measuring antioxidant activity and its application to monitoring the antioxidant capacity of wines. Agric Food Chem. Journal. 47:1035-1040.

Glynn, R. J., Ridker, P. M., Goldhaber, S. Z., Zee, R. Y. and Buring, J. E. (2007). Effects of random allocation to vitamin $E$ supplementation on the occurrence of venous thromboembolism. Report from the Women's Health Study. Circulation, Journal. 116:1497-1503.

Halliwell B., Guttridge J. M., Aruoma O. I. (1987). Hydroxyl radical scavenging activity. Analytical biochemistry Journal. 165: 215-219.

Hasan, S. M., Hossain, M. M, Faruque, A., Mazumder, M. E., Rana MS, Akter R. and Alam, M. A (2008). Comparison of antioxidant potential of different fractions of Commelina benghalensis Linn. Bang. Life. Sci. Journal. 20 (2): 9-16.

John F. R. and Bernard J. W. (1990). Biochemical Techniques: Theory and Practical. Waveland press, Inc, USA. P. 232.

Kayden, J. H., Chow, C. K. and Bjornson, L. K. (1973). Spectrophotometric method for the Determinationn of Tocopherol in Red Blood Cells. Lipid Research, Journal. 14: 533-540.

Kochuthressia K.P. and Jaseentha M.O. (2015). Phytochemical Investigation of Active Compounds In Morinda citrifolia Leaves. Asian Biochemical and Pharmaceutical Research Journal. 4 (5): 2231-2560.

Li, Y. and Schellhorn, H. E. (2007). New developments and novel therapeutic perspectives for vitamin C. Nutr, Journal. 137:2171-84.

Mantena, S. K., Jagdish, S. R., Siripurapu, K. B and Unikrishnan, M. K. (2003). In vitro

Evaluation of antioxidant properties of Cocos nucifera Linn. water, Nahrung. Food, Journal. 2:126-131.

Oyewole, O. I. and Ak igbala, P. F. (2011). Phytochemical Analysis nd Hypolipidemic Properties of Jatrophatan jorensis Leaf Extract. Eur.Med. plants, Journal. 1(4): 180-185. 
Plummer, D. T. (1978).Introduction to Biochemistry. McGraw-Hill Book Company United Kingdom Limited, England. Pp. 213214.

Rahman, M. A. and Moon, S. S. (2007). Antioxidant polyphenol glycosides from the Plant Draba nemorosa. Bull. Korean Chem. Soc. Journal. 28(5): 827-831.

Rozina P., Sukalayan, K. K. and Pijush, S. (2012). In Vitro Nitric Oxide Scavenging Activity Of Methanol Extracts Of Three Bangladeshi Medicinal Plants. The Pharmaceutical Innovation Journal. 1(12): 83-88.

Shahidi, F. and Zhong, Y. (2010) Novel Antioxidants in Food Quality Preservation and Health Promotion. Eur. Lipid Sci. and Technol. Journal. 112: 930-940.
Skrzydlewska, E. (2003). Toxicological and metabolic consequences of methanol poisoning. Toxicology Mechanical Methods. 13(4):277-93

Srinivasanan, V. and Durairaj, B. (2014) Antioxidant and Free Radcal Scavenging effect of Morinda Citrifolia Fruit Extract. International Pharmacy and Pharmaceutical Sciences, Journal. 6: 4.

Webbi, D. (2013). Phytochemicals' Role in Good Health. Today's Dietitian Journal 15(9):70.

Yu. W., Zhao, Y. and Shu, B. (2003.).The radical scavenging activities of radix puerariae isoflavonoids: A chemiluminescence study. Food Chem. Journal. 86: 525-529.

\section{$\underline{\text { How to cite this article }}$}

Ezenwaka, C. J., Uzoegwu, P. N., Nwaka, A. C. and Alaebo, P. O. (2018). Comparative Study of Antioxidant Potentials of Methanol Fruit Extracts of Morinda citrifolia and Morinda lucida. Tropical Journal of Applied Natural Sciences, 2(2): 126-131. Doi: https://doi.org/10.25240/TJANS.2018.2.2.16. 